\title{
Importance of high altitude wetlands for protection of avian diversity in the Hindu Kush Himalayas
}

\author{
Hem S Baral ${ }^{1}$, Bishnu B Bhandari ${ }^{2}$ \\ Corresponding author : Hem S. Baral \\ Email : hem_baral@gmail.com
}

The Hindu Kush-Himalayan Mountains extend over $3500 \mathrm{~km}$, cover 3.5 million $\mathrm{km}^{2}$ and include parts of Afghanistan, Bangladesh, Bhutan, China, India, Nepal, and Pakistan (Guija et al. 2003). The region is bounded by the highly fertile Gangetic plains to the south and the Tarim Basin in the north. To the east is a continental scarp that extends from the Khingan Range in northeastern China through the Taihang Mountains to the eastern edge of the Yunnan-Guinzhou Plateau separating the low-lying areas of China from the QuinghaiTibetan Plateau. Extremes in altitude, relief, climate, geology, and geomorphology provide an environment that supports a complex mosaic of landscapes (Trisal 2009). All the major rivers in the Hindu Kush-Himalayan (HKH) countries, including the Indus, Ganges, Brahmaputra, Yangtze, Mekong, Amu Darya, and Hilmand, originate in high-altitude lakes and wetlands (Guija 2005). A number of wetlands is known to occur in the Hindu-Kush Himalayan region in the form of lakes. In Nepal and Bhutan alone, there are 5000 high altitude lakes (Mool et al. 2001). However, most large lakes are found in the Tibetan plateau of China and northwestern part of the HKH region (Ranade 2008).

The Hindu-Kush Himalayan region supports an exceptionally high biodiversity and several studies have been conducted in the area on various aspects of ecosystems (Denniston 1993). However, there is general lack of understanding of the biodiversity of the high altitude regions and understanding of ecosystems dynamics is poor. The conservation and wise use of wetlands in these areas is severely constrained by a lack of information on their physical and ecological functioning and services (Pradhan and Shilpkar undated). There are interesting east-west changes in the distribution of flora and fauna, and several species are endemic to the region (Polunin and Stainton 1984, Ali and Ripley 1987, Grimmett et al. 1998, Rasmussen and Anderton 2005). There are also several species that are endemic to some valleys and smaller parts of the region (Polunin and Stainton 1984, Samant et al. 1993, WWF 2009).

The programme on Important Bird Areas (IBAs) identified 1,106 IBAs in the eight member countries of the HKH, of which around 30\% (330 IBAs) are within the HKH per se. However, $73 \%$ of the total IBAs in terms of area and $57 \%$ in terms of number are outside the existing PA network (Chettri et al. 2008). The exact number of bird species in the region

\footnotetext{
${ }^{1}$ Himalayan Nature

${ }^{2}$ Integrated water and Hazard Management (IWHM) International Centre for intertated Mountain Development
} 
is unknown. However, the range states of Hindu-Kish Himalayas boast more than 1500 bird species. The HKH is the meeting point of Palearctic and Indo-Malayan fauna and flora. In the region, there are 126 species of globally threatened birds and an additional 85 species that are currently considered near-threatened (BirdLife International 2009).

Avian diversity in the high altitude wetlands has been studied only for a few lakes and rivers (Buckton 1998, Mishra and Humbert-Droz 1998, Guija et al. 2003, Prins and van Wieren, 2004, Bhandari 2005, Bhandari and Joo 2007). This is in contrast to a relatively higher number of bird studies in the lowland and midhill lakes of the region (summarized in Bhandari et al. 1994, Bhandari 1998, Sah 1997, IUCN Nepal 2004, Jha 2008).

High altitude wetlands within the Hindu-Kush Himalayas are important as breeding areas for several wetland bird species and for many more as a staging areas. Some of the globally threatened species that are known to use or possibly use these high altitude lakes are Baer's Pochard Aythya baeri, Baikal Teal Anas formosa, Marbled Teal Marmaronetta angustirostris and the elegant Black-necked Crane Grus nigricollis. A study conducted in high altitude lakes in Ladakh found at least 14 species of birds that depend on wetlands, including the breeding of the globally threatened Black-necked Crane (Mishra and Humbert-Droz 1998). A total of 67 bird species is said to be associated with high altitude wetlands including the Wood Snipe Gallinago nemoricola, another globally threatened species (Baral 2005, 2007). Avian diversity and population seems to be high in larger-sized lakes and glaciated broader valleys with rivers and streams. As most of these features are concentrated in the westernmost part of the Hindu-Kush Himalayas, the wetlands in this part tend to be much richer in avian fauna compared to the eastern part. In particular, the Ladakh region of India and Mansarovar and associated lakes in China are famous for several species of breeding water birds. Many of these birds winter farther south in the plains of the subcontinent during winter.

Several other more common bird species also breed in the high altitude wetland areas, including Bar-headed Goose Anser indicus, Ruddy Shelduck Tadorna ferruginea, Common Merganser Mergus merganser, Great Crested Grebe Podiceps cristatus, Black-necked Grebe Podiceps nigricollis, Brown-headed Gull Larus brunnicephalus and Green Sandpiper Tringa ochropus. The Bar-headed Goose is famous for its spectacular migration over the Himalayas and have been observed flying at a height of $9375 \mathrm{~m}$ above Everest (Inskipp and Inskipp 1991). This is the highest altitude recorded for a bird on its routine migration.

It is well known that species richness decreases with higher elevations (Roy and Behera 2005). In general terms, species richness decreases from east to west of the Hindu-Kush Himalayan region. However, this general statement may not hold true for the biodiversity of the high altitudes in the HKH region. It is likely that the high altitude area in the western part of the HKH range is more biodiverse than the east. The most important of the high altitude biodiversity is the uniqueness and high level of endemism that is less evident in other parts within the HKH region. The high altitude ecosystem is extremely fragile and is as sensitive to anthropogenic disturbance as other habitats (Denniston 1993). This makes the region very special in terms of biodiversity and its conservation (Ives 2004). 


\section{Threats to High Altitude Wetlands}

Various studies suggest that warming in the Himalayas has been much greater than the global average of $0.74^{\circ} \mathrm{C}$ over the last 100 years (IPCC 2007; Du et al. 2004). The lakes and rivers in the $\mathrm{HKH}$ are therefore extremely sensitive to the effects of climate change.. Climate change impacts on the physical characters of lakes and rivers will have a direct effect on biodiversity (Lacoul and Freedman 2005). Currently, many of the high altitude lakes in the HKH tend towards an oligotrophic state (Khan and Shah undated) which is likely to be altered with climate change (Callot et al. 2009). The alteration of current climates increases the risk of extinction for species with narrow geographic or climatic distributions and the disruption of existing communities. Most endemic plant species may be unable to respond successfully as the rate of climate change increases and resultant invasions of weedy and exotic species from lower elevations bring accompanying problems (McCarty 2001). No detailed investigations of snow and ice processes or their relevance to climate have taken place in most areas of the Himalayan and other high ranges (Jianchu et al. 2007). There is a lack of proper understanding about what possible changes climate change effects may bring to high altitude wetland and migratory birds. Some have predicted that migration of birds may be disrupted (Doswald et al. 2009) that avifaunal assemblages will change (Gregory et al. 2009) and that the habitat for some specialist species may disappear (Baral 2002). Climate change is already affecting many bird populations globally and many are in decline (Wormworth and Mallon 2006, Moller et al. 2008). In general, climate change is believed to be affecting all natural ecosystems, as well as food production in agricultural systems, tourism, and mountain infrastructure (Jianchu et al. 2007).

Aquaculture of cold water fish species has been trialled in several states of India (Raina and Petr undated) and may present a threat to some species of waterbirds. The importance of the lakes for their unique flora and fauna and as staging and breeding areas for waterbirds should be assessed before the introducing fish farming. The conservation value of many important lowland lakes and wetlands have already been compromised by inappropriate fish farming. Consequently, remaining lowland lakes and wetlands that are unaffected by fish farming have become even more valuable for conservation. This will also be the case for high altitude wetlands.

The ecosystem balance that traditionally characterized trans-Himalayan Buddhist communities is degenerating because of unmanaged tourism (Goldstein 1981). Developmental activities and increasing tourism threaten high altitude wetlands (Mishra and Humbert-Droz 1998). Lake tourism in the HKH is mostly unmanaged with respect to in biodiversity protection. Most cases that have been investigated have shown a decrease in the biodiversity value of the wetlands following the initiation of tourism (Ranade 2008). Tourism and biodiversity conservation can be compatible only when appropriate monitoring programmes are implemented and management authorities are able to respond to any deleterious changes. The wise use of wetlands has frequently been proposed but there remains considerable disparity between theory and practice (Bhandari 2009). 
Grazing is a significant threat to many ground nesting bird species including wetland breeding species. Therefore during the breeding season (usually March to July), some areas should be fenced or otherwise protected from grazing and trampling. However, carefully managed grazing can be a useful tool for the management of some lake shores, and wetland systems.

Wetland loss is a threat to ecological balance (Prasad et al. 2002) which in turn can lead to other undesirable consequences (Maikhuri et al. 2009). Therefore, the conservation of high altitude wetlands is important for both human communities and biodiversity.

\section{Conclusion}

Various issues have been raised and discussed regarding the conservation of biodiversity of mountain regions and environments (Sharma 2009). Strengthening of regional initiatives for wetland conservation in the HKH region requires a landscape level approach. Such initiatives are already underway (Lei 2005, ICIMOD undated) and need support from all sectors. Sound strategies for the implementation of such policies are needed both at landscape level and in many cases focussed to certain areas (Oommen undated). Landscape level conservation, corridor and connectivity preservation as well as work on focussed sites are required concurrently if significant progress on wetland conservation is to be made within the high $\mathrm{HKH}$ region.

\section{References}

Baral, H. S. 2002. Impact of climate change on Nepal's birds. Danphe 11(4): 6.

Baral, H. S. 2005. Avian Fauna in the High Altitude Lakes of Nepal Himalayas. pp53-58. In Bhandari, B. B. (2005). High Altitude Wetlands of Nepal: Views and Reviews on Conservation. The Procedings of the National Workshop on High Altitude Wetlands of Nepal. Forum for Ecosystem Management, Kathmandu.

Baral, H. S. 2007. Ornithological Importance of the Gosaikunda Area. pp. 45-49. In Bhandari, B. B. and Joo, G. J. (2007). Gosaithan: A Sacred Wetland in Nepal. Nepal Wetlands Society, Kathmandu.

Baral, H. S. 2008. Himalayan Wetlands and Birds. In Water Tower of Asia: Experiences in Wetland Management in Nepal. In Bishnu B. Bhandari, Seung Oh Suh and Sung Hoon Woo (Eds) Chanwon: Gyeongnam Ramsar Environmental Foundation (GREF).

Bhandari, B. 1998. An inventory of Nepal's Terai Wetlands. Final Report. IUCN Nepal, Wetlands and Heritage Unit, Kathmandu, Nepal.

Bhandari, B. B. 2005. High Altitude Wetlands of Nepal: Views and Reviews on Conservation. The Procedings of the National Workshop on High Altitude Wetlands of Nepal. Forum for Ecosystem Management, Kathmandu. 
Bhandari, B. B. 2009. Wise use of Wetlands in Nepal. Banko Jankari Special Issue. pp.10-17.

Bhandari, B. B. and Joo, G. J. 2007. Gosaithan: A Sacred Wetland in Nepal. Nepal Wetlands Society, Kathmandu.

Bhandari, B., Shrestha, T. B. and McEachern, J. (Eds) 1994. Safeguarding Wetlands in Nepal. Proceedings of the National Workshop on Wetlands Management in Nepal, 3-5 March 1993. IUCN Nepal, Kathmandu, Nepal.

BirdLife International 2009. www.birdlife.org downloaded on 18 November 2009.

Buckton, S. T. 1998. Spatio-temporal patterns in the distribution and ecology of river birds. Ph.D. Thesis, Cardiff, UK University of Wales. Unpublished.

Callot, B., Harjung, J., van de Löcht, J., Unterköfler, R. 2009. Climate Change Himalayas. Faculty of Earth Sciences, University of Iceland. Pp.21.

Chettri, N., Shakya, B., Thapa, R., Sharma, E. 2008. Status of a protected area system in the Hindu Kush-Himalayas: An analysis of PA coverage. International Journal of Biodiversity Science Management 4: 164-178.

Denniston, D. 1993. Saving the Himalayas. Worldwatch. 1 November 1993.

Doswald, N., Willis, S. G., Collingham, Y. C., Pain, D. J., Green, R. E., and Huntley, B.2009. Potential impacts of climatic change on the breeding and non-breeding ranges and migration distance of European Sylvia warblers. Journal of Biogeography 1-15.. doi:10.1111/j.1365-2699.2009.02086.x.

Du, M.Y.; Kawashima, S.; Yonemura, S.; Zhang, X.Z.; Chen, S.B. 2004. Mutual Influence between Human Activities and Climate Change in the Tibetan Plateau during Recent Years. In Global and Planetary Change, 41: 241-249.

Goldstein, M. S. 1981. High-altitude Tibetan populations in the remote Himalaya: social transformation and its demographic, economic, and ecological consequences. Mountain Research and Development 1: 5-18.

Gregory R. D., Willis S.G., Jiguet F., Vor`1'šek P., Klvan`ova' A. et al. (2009). An Indicator of the Impact of Climatic Change on European Bird Populations. PLoS ONE 4(3): e4678. doi:10.1371/journal.pone.0004678.

Guija, B. 2005. WWF International's Regional Approach to Conserving High-Altitude Wetlands and Lakes in the Himalaya. Mountain Research and Development 25(1): 76-79.

Guija, B., Chatterjee A., Gautam, P. and Chandan, P. 2003. Wetlands and Lakes at the Top of the World. Mountain Research and Development 23(3): 219-221.

ICIMOD (undated). Water \& Climate Change Adaptation: ICIMOD's Strategy \& Actions. International Centre for Integrated Mountain Development, Kathmandu, Nepal.

IPCC 2007. Climate Change 2007: The Physical Sciences Basis. In Summary for Policy Makers, IPCC: 21. IPCC, Geneva. 
IUCN Nepal 2004. A Review of the Status and Threats to Wetlands in Nepal. IUCN Nepal, Kathmandu.

Ives, J. D. 2004. Himalayan perceptions: Environmental change and the well-being of mountain peoples. Himalayan Journal of Sciences 2(3): 17-19.

Jha, S. 2008. Status and Conservation of Lowland Wetlands in Nepal. Our Nature 6: 67-77.

Jianchu, X, Shrestha, A., Vaidya, R., Eriksson, M., and Hewitt, K. 2007. The Melting Himalayas. Regional Challenges and Local Impacts of Climate Change on Mountain Ecosystems and Livelihoods. International Center for Integration and Mountain Development, Kathmandu.

Khan, M. A. and Shah, M. A. (undated). Hydrology and Sediment Loading of Hokersar Wetland Sanctuary in the Kashmir Himalaya, India. Pp 899-910.

Lacoul, P. and Freedman, B.2005. Relationships between aquatic plants and environmental factors along a steep Himalayan altitudinal gradient. Aquatic Botany 84(1): 3-16.

Lei, G. 2005. Review of the Himalayan Wetland Conservation Initiative. CONVENTION ON WETLANDS (Ramsar, Iran, 1971), Asia Regional Meeting in preparation for Ramsar COP9, Beijing, China, 13-16 May 2005.

Maikhuri, R. K., Rawat, L. S., Negi, V. S., Phondani, P., Bahuguna, A., Chamoli, K. P., and Farooquee, N. 2009. Impact of Climate Change and Coping Strategies in Nanda Devi Biosphere Reserve Central Himalayas, India Pp.138-148. In Sharma, E. (Ed) (2009). Proceedings of the International Mountain Biodiversity Conference Kathmandu, 16-18 November 2008. International Centre for Integrated Mountain Development, Kathmandu, Nepal.

McCarty, J.P. 2001. 'Ecological Consequences of Recent Climate Change'. In Conservation Biology, 15(2): 320-331.

Mishra, C. and Humbert-Droz, B. 1998. Avifaunal survey of Tsomoriri Lake and adjoining Nuro Sumdo Wetland in Ladakh, Indian trans-Himalaya. Forktail 14: 67-70.

Møller, A. P., Rubolini, D., and Lehikoinen, E. 2008. Populations of migratory bird species that did not show a phenological response to climate change are declining. PNAS 105(42): 16195-16200.

Mool, P. K.; Wangda, D.; Bajracharya, S. R.; Kunzang, K.; Gurung, D. R.; Joshi, S. P. 2001. Inventory of glaciers, glacial lakes and glacial lake outburst floods: monitoring and early warning systems in the Hindu Kush-Himalayan region, Bhutan. ICIMOD, Kathmandu.

Oommen, M. A. (undated). Trans Himalayan Biodiversity Conservation and Society. PDF Pp 19.

Pradhan, S. and Shilpakar, R. (undated). The Asian Wetlands Inventory (AWI) approach for enhancing inventory, monitoring and management of wetlands in Himalaya. ICIMOD, Nepal., PDF Pp 10. 
Prasad, S. N., Ramachandra, T. V., Ahalya, N., Sengupta, T., Kumar, A., Tiwari, A. K., Vijayan, V. S. and Vijayan, L. (2002). Conservation of wetlands in India: a review. Tropical Ecology. 43(1): 173-186.

Prins, H. H. T. and van Wieren, S. E. (2004). Number, population structure and habitat use of bar-headed geese Anser indicus in Ladakh (India) during the brood-rearing period. Acta Zoologica Sinica 50(5): 738-744.

Raina, H. S. and Petr, T. (undated). Coldwater fish and fisheries in the Indian Himalayas: lakes and reservoirs. http://www.fao.org/docrep/003/x2614e/x2614e05.htm

Ranade, P. S. (2008). Managing Lake Tourism: Challenges Ahead. Conference on Tourism in IndiaChallenges Ahead 15-17 May 2008, IIMK. Pp. 543-554.

Roy, P. S. and Behera, M. D. (2005). Assessment of biological richness in different altitudinal zones in the Eastern Himalayas, Arunachal Pradesh, India. Current Science 88(2): 250-257.

Samant, S.S., Dhar, U. and Rawal, R.S. (1998). Biodiversity status of a protected area in West Himalaya. Askot Wildlife Sanctuary. Int. J. Sustain. Dev. World Ecol. 5: 194-203.

Sharma, E. (Ed) (2009). Proceedings of the International Mountain Biodiversity Conference Kathmandu, 16-18 November 2008. International Centre for Integrated Mountain Development, Kathmandu, Nepal.

Sharma, E., Tsering, K., Chettri N. and Shrestha, A. 2009. Biodiversity in the Himalayas - Trends, Perceptions, and Impacts of Climate Change. In Sharma, E. (Ed) 2009. Proceedings of the International Mountain Biodiversity Conference Kathmandu, 16-18 November 2008. International Centre for Integrated Mountain Development, Kathmandu, Nepal.

Trisal, C. 2009. Wetlands of the Hindu Kush-Himalayas - Ecosystem Functions, Services and Implications of Climate Change 169-178 in Sharma, E. (Ed) (2009). Proceedings of the International Mountain Biodiversity Conference Kathmandu, 16-18 November 2008. International Centre for Integrated Mountain Development, Kathmandu, Nepal.

Wormworth, J., Mallon, K. 2006. Bird Species and Climate Change. World Wide Fund for Nature Australia. Sydney, Australia.

WWF 2009. The Eastern Himalayas: Where Worlds Collide. Living Himalayas Initiative, WWF, Kathmandu. 